toms of cholera and their treatment, that I have ventured to mention facts observed by myself, and more or less corroborated by others; hoping that by this means, should another visitation of this fearful malady come upon us, we may be more prepared to meet it. I was induced to write, seeing the letter of Dr. Macloughlin in your last week's number.

$$
\text { I am, Sir, yours, \&c., }
$$

Joseph ALlen,

July, 1857. Junior House-Surgeon to the Royal Infirmary, Liverpool.

\section{HOSPITAL PHYSICIANS AND SURGEONS.}

To the Editor of THe LANCET.

SIR, - I venture to believe that the able letter, under the above heading, from Chirurgus, in your journal of the 18th inst., must have struck the majority of your readers as a temperate exposition of serious evils, - -evils alike affecting the development of science, the honour of the profession, and the public interest. Many spontaneously give expression, in private, to their disapprobation of the present system of hospital appointments; no one, I presume, would defend the system generally prevailing : yet it flourishes, chiefly, I apprehend, because opinion is not expressed upon it in the only way likely to prove effective.

It is contemplated to draw up a statement of the evils attendant upon the present system, with the signatures of such men as are convinced of the necessity for reform, and are entitled by their professional status to claim consideration for their judgment on such a matter. Allusions to special institutions will be most sedulously avoided, it being felt that the evil is so general, so clearly demonstrable, and so pernicious, that its simple statement on good authority must attract such attention as at least to lay the foundation for remedial procedure.

Under these circumstances, I trust your correspondent Chirurgus will favour me with his name. In return, I shall be happy to favour him, or any of your readers, with the names of thcse who have joined for the purpose mentioned.

I remain, Sir, your obedient servant,

Upper Woburn-place, Russell-square, J. S. GAMGEE, M.R.C.S. July, 1857 .

\section{THE MARSHALL HALL METHOD OF TREAT. MENT IN ASPHYXIA. \\ To the Editor of THE LANCET.}

Sir,-Permit me, through the medium of your columns, to record another successful case of the employment of Dr. Marshall Hall's Method in the treatment of asphyxiated new-born infants. On the $22 \mathrm{nd}$ of May last, I was called to attend a young married woman in her second confinement, during the absence of her usual medical attendant. On examination, I found the head with a loop of the funis presenting, and previous to the birth of the child all circulation in the cord had ceased from the pressure exerted on it between the parts of the mother and the head of the fotus. Upon expulsion, the child was apparently lifeless; the face and lips were perfectly blue, and not the slightest pulsation could be detected in the heart. The usual remedies of dashing cold water, \&c., on the face and chest failing in restoring animation, without waiting to tie the funis, I immediately adopted the postural method recommended by Dr. Marshall Hall for inducing artificial respiration, and caused that act to be performed about fifteen times in a minute. After a few minutes' trial the child gave a feeble gasp, and continued to do so every ten or twelve turns. The intervals between the respiratory movements soon became shorter, and in half an hour it breathed. It appeared, however, in a semi-comatose state, and was some time before it became warm and could move its limbs. Even then the heart beat feebly, and at only half its normal frequency. The child from this time slowly improved, and is now a strong and healthy infant.

I am, Sir, your obedient servant,

Charing-cross Hospital, July, 1857. HoRatio G. SkrnNer.

\section{INAUGURATION OF THE STATUE OF BICHAT.}

THis ceremony took place, on the 16 th inst., in the courtyard of the Faculty building, the space, for the occasion, being overhung by an awning, and transformed into a magnificent hall. The Minister of Public Instruction, the representatives of the learned bodies and societies, and a numerous concourse of medical men and students were present. A military band played the "Imperial March," and the veil was removed from the statue. Choral voices then begun to sing the cantata written for the occasion by Dr. A. L. Roux, the music by M. Elwart. Speeches were subsequently made by the Minister of Public Instruction; by M. A. Latour, as secretary to the permanent committee of the Congress of 1845 (by whom the statue has been presented to the Faculty); by M. Serres, in the name of the Congress; by Messrs. Paul Dubois and Bouilland, in the name of the Faculty of Medicine; and by M. Larrey, in the name of the Société Médicale d'Emulation, founded by Bichat.

The most remarkable discourse amongst those which were delivered, and one which expressed in eloquent terms the aspirations, sufferings, and ill-requited devotion of the medical profession in France, was that of $M$. Amédee Iatour, the editor of $L$ 'Union Médicale-a man who for many years has used his facile and brilliant pen in defence of the great questions which bear on the welfare and dignity of our profession.

After this manner were the remains of Bichat, after forty three years' inhumation, taken up with the honours due to his genius. The Medical Congress was closing its session, when it was rumoured that, owing to some territorial changes, the remains of Bichat, buried in an obscure corner of the St. Catherine Cemetery, would soon be lost to the profession. The meeting was at once unanimons, and it was resolved, after an eloquent address by Professor Malgaigne, that the body should be exhumed, and transferred, with the proper honours, to the Eastern Cemetery, where the Municipal Council had gratuitously granted a site. Much difficulty was experienced in reaching the body, many others being superposed; at last it was recognised by an unmistakable sign, and carried with great solemnity to its final resting-place. It was at the same time resolved that a statue should be erected to the great physiologist in Paris, his adopted city, a similar memorial having already been placed in the principal square of Bourg, a town situated near Bichat's birthplace. A subscription was opened, which was filling rapidly, when the revolution of 1848 paralysed efforts of this kind. With true artistic liberality, David (d'Angers) agreed to lend his chisel without remuneration; and now, twelve years after the meeting of the Congress, the committee were enabled to offer the statue (the late David's last work) to the faculty.

M. Latour, after completing this historical ancount, of which the preceding lines are a faint epitome, dilated, in an impressive and eloquent manner, upon the wrongs of the profession, who have not yet obtained the reforms promised during the sitting of the Congress, and which were embodied in. a Bill swept away by the events of 1848 .

"Since that period," said the orator, "the medical family of France have stood by their imperilled country. They suffered bitterly from civil discord, but concealed their misfortunes, and would not divert the attention of the ruling powers from the work of reconstruction required after political com. motions. The medical men of France sacrificed all to their conntry, even the right of making known their grievances. They remained silent as if their most ardent wishes were satisfied by scientific researches, by the fatigue of practice, by contending against epidemics (those battle-fields of the medical man in civil life), by the perils of the Crimean campaign, by the dangers on the Black Sea and the Baltic; doing every. where courageously and firmly their duty, and showing themselves worthy heirs of the great medical generation to which Bichat belonged, worthy descendants of such benefactors of humanity as Dupuytren, Boyer, Desgenettes, Larrey, Corvisart, Broussais, Laënnec, and so many others who have raised medical science so high in the estimation of men! (Vehement applause.) Therefore is it, because medical men have shown themselvcs patient, high-minded, and noble-hearted, surrounded by suffering and disappointment, because they did not once swerve from the path of duty, that they deserve the sympathy of the ruling power. Let this government, which has given France tranquillity, the glory of the battle-field, and $a$ no less glorious peace, take up the wishes of the great congress of 1845 , more for the benefit of society than the profession. Medical men do not ask for corporate restrictions and privileges. No, they ask (and this is certainly not common in the history of professions) that society should exact greater guarantees from them, in placing medical studies on a higher footing; they ask for proper classical preliminary education, (which has lately been done away with,) and that the public should take in hand, in self-defence, measures of repression against impostors who trade on public credulity; they ask for the abolition of the inferior medical deyree (officiers de sante), because the tiller of the land has as much right as the rest of 